\title{
Depositional environment and diagenesis of Asmari Formation in the well-A (oilfield at western Lorestan basin) and Syah-koh Anticline (Zagros fold-thrust belt, west Iran): microfacies, sequence stratigraphy and geochemistry
}

Zahra Mohammadi ( $\nabla$ zahra.mohammadi@kuleuven.be)

KU Leuven: Katholieke Universiteit Leuven

\section{Sajjad Gharechelou}

University of Tehran

\section{Mahtab Mozafari}

University of Parma: Universita degli Studi di Parma

Mohsen Liyaghat

Shahid Beheshti University

Mahmoud Jalali

National Iranian Oil Co

Rudy Swennen

KU Leuven: Katholieke Universiteit Leuven

\section{Research Article}

Keywords: Asmari Formation, microfacies, depositional setting, geochemistry, Zagros (Iran)

Posted Date: March 15th, 2021

DOl: https://doi.org/10.21203/rs.3.rs-316560/v1

License: (c) (i) This work is licensed under a Creative Commons Attribution 4.0 International License.

Read Full License 


\section{Abstract}

The Asmari Formation (Oligocene-Miocene), as one of the main carbonate petroleum reservoirs of the Middle East, represents strongly variable reservoir quality on regional and local scale. One outcrop analogue (Syah-koh Anticline) and a well-A (oilfield at western Lorestan basin), both situated in western Iran, were investigated to address the reservoir characteristics. The 12 microfacies identified reflect deposition on a broad carbonate ramp reflecting an outer, mid and inner ramp setting. Three third-order depositional sequences are deduced based on interpreted Gamma-ray, sonic logs and stratal stacking patterns. The identified sequences and existence of a thicker evaporite succession in well-A points to more restricted depositional conditions with reduced connection to the open sea from the Syah-koh Anticline towards well-A. The diagenetic modifications revealed micritization, dissolution, cementation, fracturing, dolomitization and compaction. Petrographic and $\delta^{13} \mathrm{C}$ and $\delta^{18} \mathrm{O}$ analysis of cements points towards marine, meteoric and burial diagenetic alteration, whereby the cements with $\delta^{13} \mathrm{C}$ and $\delta^{18} \mathrm{O}$ values similar to those of enclosing micrite ( 0 to $-2 \%$ o-PDB) reflect a marine diagenetic environment. The micrite phases enriched in aforementioned isotopes resulted from evaporation which is supported by widespread associated dolomitization. The $\mathrm{J}$ trend present in the $\delta^{13} \mathrm{C}$ and $\delta^{18} \mathrm{O}$ cross plot reflects the meteoric diagenetic overprint. The cements with highly depleted $\delta^{18} \mathrm{O}$ signatures (<-10\%o V-PDB) are linked to burial diagenetic processes. The isotopic values are in agreement with the luminescence characteristics of the cements including dull for marine, alternating bright and dull zones for meteoric and bright for burial cements.

\section{Introduction}

The Asmari Formation (Late Oligocene - Early Miocene) is one of the major hydrocarbon reservoirs in the Zagros region of Iran. This formation at its type section in Tang-e Gel-e Tursh (southern Iran) (Motiei, 1993) consists of limestones, dolomitic limestones and argillaceous limestones. Geological investigations of this formation started already since the early 20th century by Busk and Mayo (1918) and continue till today. Several studies have been carried out on microfacies, especially addressing the depositional environments and sequence stratigraphy of the Asmari Formation (e.g. Motiei, 1993; Seyrafian and Hamedani, 1998, 2003; Vaziri-Moghaddam et al., 2006, 2010; Rahmani et al., 2009; Van Buchem et al., 2010; Dill et al., 2010; Sadeghi et al., 2011; Daraei et al., 2015; Hosseini et al., 2016; Adabi et al., 2016; Gharechelou et al., 2016 and 2018). However, the extensive regional distribution of this formation in the Zagros Basin, its paleo-climate and tectonic setting causes a large variability in microfacies that subsequently were affected by diagenetic processes. Due to this variability, no specific study can fully address all reservoir aspects of this formation in the entire Zagros. For instance, the most obvious variability, reported by Motiei (1993), is that the evaporitic Kalhor Member transitionally changes to limestone of the middle Asmari Formation in the northwestern part of the Zagros Basin, whereas in the southeast it changes to the sandy Ahwaz Member. Consequently, the study of reservoir analogues nearby different oil-fields of Asmari in Zagros can provide complementary information. 
In this study two sections of the Asmari Formation in the Lorestan Basin have been assessed, i.e. a surface section in Syah-koh Anticline and a subsurface section in well-A (oilfield in the western part of Lorestan Basin). The aim is to reconstruct the depositional environment and to provide a relevant sequence stratigraphy model, which both are essential to understand and improve the predictive aspect of economic exploration and production (as shown in Catuneanu, 2006) of the Asmari Formation. Moreover, the diagenetic modifications of the studied intervals and related processes have been investigated. This study is based on field work and systematic sampling, petrography, and stable carbon as well as oxygen isotope analyses.

\section{Geological Setting}

The Zagros Basin formed as a foreland basin in response to the development of Zagros Mountain Belt, which is part of the Alpine-Himalayan system of Iran, extending from the NW border of Iranian through to SW of Iran. It is divided into two main structural units from south to north: the Zagros Fold-Thrust Belt and High Zagros Belt. The Zagros Fold-Thrust Belt corresponds to the tectonically deformed part of the Zagros sedimentary basin. This occurred during Early Cretaceous to Recent Zagros orogeny (Alavi, 2007) and extends for about 2000 kilometers from SE Turkey through northern Syria and Iraq to W and S Iran. This belt which contains numerous supergiant hydrocarbon fields is divided into several zones (i.e. Lorestan, Izeh, Dezful Embayment, Fars), that differ according to their structural style and sedimentary history (Falcon, 1961; Berberian and King, 1981; Motiei, 1993). The Izeh zone and Dezful Embayment are separated from Lorestan and Fars by the Balarud and Kazerun faults, respectively (Falcon, 1974; Motiei, 1993). Detailed descriptions of the geology of the Zagros Mountains are given by several authors (e.g. Kashfi 1976; Farhoudi 1978; Alavi 1980; Ghavidel-Syooki 1995). Cenozoic formations in SW Iran made important petroleum system of Zagros basin (Fig. 1).

The study area is located in the SW-part of Lorestan Basin (Fig. 2). An excellent section of Asmari Formation with a thickness of about $283 \mathrm{~m}$ is exposed at the upper part of Syah-koh Anticline (Fig. 3). This section displays a sharp conformable contact with the underlying Pabdeh and overlaying Gachsaran Formations (Fig. 3). In this area, the Asmari Formation can be subdivided into a lower Amari (53 m), middle Asmari ( $98 \mathrm{~m}$ ) which is equivalent to the Kalhor Member and upper Asmari (132 $\mathrm{m}$ ). The section in the well-A drilled in an oilfield at the W-part of Lorestan Basin penetrates the lower Amari (52 m), Kalhor Member (50 m) and upper Asmari (50 m).

\section{Methods}

In this study 63 thin sections from Syah-koh and 300 samples (cuttings) from well-A were stained with potassium ferricyanide and alizarin-red S (Dickson, 1965). Detailed petrographical and sedimentological analyses based on the macroscopic description (bed geometry, texture, sedimentary features, and faunal content) and characteristics of accessory grains and matrix composition served as evidence for deducing microfacies, sequence stratigraphy, paleoenvironmental reconstruction and identification of diagenetic products. Microscope analysis has been done by an Olympus BX60, Leica DM LP Parallel and Crossed 
Polar Optical and Cathodoluminescence (CL: using a modified Technosyn 8200MK2 instrument at $10 \mathrm{kV}$ and 300-400 $\mu \mathrm{A}$ gun current). Moreover, a scanning electron microscope (SEM, model Hitachi TM-1000) with magnifications up to 11000x was used to study the micro-fabrics of fresh-cut, un-polished surfaces. The classification of studied carbonate rocks follows the nomenclature of Dunham (1962), while microfacies and their depositional setting are compared to standard ramp microfacies (RMF) descriptions by Wilson (1975), Pedley (1996) and Flügel (2010). Sequences are defined as system tracts based on two main surfaces (i.e. maximum flooding surfaces (MFS) and sequence boundaries (SB)). Arabian Plate sequences reported by Haq and Al-Qahtani (2005) together with universal sequences (Ogg, et al., 2016) are compared with the results obtained in this study. Stable carbon and oxygen isotopes were analysed at KU Leuven on a Thermo Delta V Advantage isotope ratio mass spectrometer coupled to a GasBench II. The analytical procedure is the same as reported in Mohammadi et al. (2019). For TOC 19 samples were analysed at KU Leuven. The carbonates were removed by repeated acidification with diluted $(2 \%) \mathrm{HCl}$. For the determination of \%OC (organic carbon and the stable carbon isotope composition of the $\mathrm{OC}$ fraction $\left(\delta^{13} \mathrm{C}_{\mathrm{OC}}\right)$, samples were combusted in an elemental analyser - isotope ratio mass spectrometer (EA-IRMS, ThermoFinnigan Flash $\mathrm{HT}$, and ThermoFinnigan DeltaV Advantage), and data were calibrated using an in-house Leucine and IAEA-C600 standard (caffeine).

\section{Sedimentary Microfacies}

The Asmari Formation in the studied sections consists of both skeletal and non-skeletal carbonates. Skeletal grains mainly correspond to benthic and some pelagic foraminifera, red algae, bivalves, crinoids, bryozoa and some coral fragments. Benthic foraminifera are the main skeletal component and display a broad diversity range (e.g. Operculina sp., Miliolids, Elphidum sp. Archaias sp, Dendritina rangi (Fig. 4A to F). Planktonic foraminifera consist mainly of Globigerinids (Fig. 4G). Red algae is the second most important skeletal component representing variable types like Peyssoneliacean, Subterraniphyllum and Lithophyllum (Fig. 4H to K). Non-skeletal grains consist mainly of ooids, intraclasts and peloids (Fig. 4L). Based on lithology, texture and sedimentary characteristics, 12 marine microfacies could be differentiated in the studied Asmari Formation. These microfacies reflect a succession that was deposited upon a vast extended carbonate ramp consisting of an outer, middle and inner carbonate ramp. The latter can be further subdivided into different sub-environments including shoal, open lagoon, restricted lagoon and intertidal setting. In the following discussion, the different microfacies types are described and interpreted in terms of paleoenvironment.

\section{I) Outer ramp}

Planktonic foraminifera wackestone (MF1)

This microfacies is characterized by grains floating in a micrite matrix with loose packing (Fig. 5A). Clastic carbonate grains are uncommon. The constituents of these wackestones consist dominantly of planktonic foraminifera (globigerinids and globorotalids), and rarely echinoid fragments, without benthic foraminifera and any features characteristic of shallow-water and/or high-energy sedimentation. Sand- 
sized planktonic foraminifera are the main components, which mixed with minor thin-shelled bivalves, echinoderm and ostracod shell fragments in the

context. They show intergranular and moldic porosity filled with a cement composed of calcite and iron oxide. Furthermore, replacement of rhombohedral dolomite is common.

The depositional environment is interpreted to be situated just below wave base within the photic zone of an outer ramp based on sedimentological characteristics and faunal content (cf. Buxton and Pedley 1989; Pedley 1998). Abundant planktonic foraminifera within a micritic matrix indicate calm and aphotic sedimentation conditions, below storm wave base(SWB). This interpretation is based on co-occurrence of planktonic foraminifera which can be used as index for open marine conditions (Geel, 2000) and by the fine-grained matrix. Moreover, according to Ćosović et al. (2004) the lack of benthic foraminifera and red algae indicates the lower limit of the photic zone. This microfacies occurs at the bottom of the lower Asmari.

Bioclastic wackestone/mudstone (MF2)

This microfacies is made up by bioclasts such as echinoids, bryozoans, ostracods, echinoderms and pelagic foraminifera that float in a micritic to calci-siltitic matrix (Figs. 4, 5B). In this light-yellow clayey wackestone/mudstone main planktonic fauna consists of dispersed Globigerina. Furthermore, rarely bentic large foraminifera such as Amphistegina and Lenticulina are recognized in this facies. Bioturbation and burrowing are widespread and locally the matrix is neomorphosed to microsparite. The decrease in the proportion of planktonic foraminifera and common bioturbation differentiates this microfacies from MF1.

The depositional environment of MF2 is placed below wave base in the photic zone. This interpretation is based on accumulation of planktonic foraminifera with bioclasts such as bryozoans, as well as bioturbation and muddy matrix (Wilson, 1975; Geel, 2000; Flügel, 2010).

II) Mid ramp

Operculina algal packstone/rudstone (MF3)

This microfacies is dominated by large planktonic foraminifera, especially Operculina, Miogypsina and coralline and Peyssoneliacean red algae (Fig. 5C). Additional components are fragments of corals, echinoderms and bryozoans. The packstone is composed of a variety of allochems in terms of type and size, including mainly sand to silt-sized fragments of planktonic foraminifera. The fabric is grainsupported with slightly tight packing. Foraminifera and algae display co-existence and in some cases are encrusted (see Fig. 4K). Coralline algae rudstone to packstone is a common Miocene ramp microfacies (Buxton and Pedley, 1989) comprising Echinoderm, rotalia and red algae. Both moldic and framework porosity are well developed and partially filled with cements. 
The depositional environment of this microfacies corresponds to the deepest part of a mid ramp just above the lower limit of the photic zone. This interpretation is supported by occurrence of large foraminifera such as vast range of Operculina which is often encountered in the latter environmental setting (Geel, 2000; Romero et al., 2002). Moreover, the rare occurrence of planktonic foraminifera and absence of lagoonal foraminifera like miliolids are additional arguments in support of a mid ramp setting.

Bioclastic bindstone (MF4)

This microfacies is characterized by a bindstone fabric with Peyssoneliacean red algae which trap and bind allochems and fine carbonate particles (Fig. 5D). Principal constituents which were trapped are fragments of corals, gastropods, bivalves, echinoids and benthic foraminifera. The fabric displays a tight packing with rare intergranular porosity, which is locally filled with sparitic equant cement.

The depositional environment of this microfacies corresponds to the upper part of a mid ramp situated between an euphotic and mesophotic zone below the fair-weather wave base. Although the environment of this microfacies is interpreted as low energy lagoonal environment by Rasser $(2000,2003)$, the limited presence of skeletal grains representative of low energy environment, like millolids, point toward sedimentation under relatively lower energy conditions. This suggests sedimentation at a lower energy level and deeper setting compared to the former microfacies MF3.

Oncoidal peloidal packstone to grainstone (MF5)

This microfacies is characterized mainly by oncoids (Fig. 5E) which formed by encrusting and binding of sedimentary grains. Well-sorted peloids are the second important component. The other grains consist of some bioclasts such as echinoids, benthic foraminifera, ostracods and also ooids. The fabric is grain supported with intergranular pores with sparitic infill which locally changes to a micritic matrix. The pores are partially filled by blocky calcite.

The depositional environment of this microfacies corresponds to the border of mid and distal inner ramp in the euphotic zone around fair-weather wave base. This interpretation is supported by the presence of well sorted peloids and rare ooids reflecting a hydrodynamic shoal environment of with oncoids and rare large bentic foraminifera support a moderately high-energy setting as encountered at the transition of inner to mid ramp.

III) Inner ramp

Bioclastic and ooid grainstone (MF6)

This microfacies is made up by the presence of ooids displaying an oval, circular or elongate outline and concentric internal structure (Fig. 5F) showing several cortical layers around a core which is usually dissolved. They are well-sorted and densely packed. In some cases, they are micritized. Other components consist of a broad range of peloids, benthic foraminifera and fragments of bivalves and 
gastropods. Intergranular and/or moldic are common pore types of this microfacies (Gharechelou et al. 2015).

The depositional environment of this microfacies corresponds to a distal inner ramp near-shoal to lagoon with deposition above fair-weather wave base. This interpretation is supported by the high frequency and well sorting and rounding of ooids and peloids making-up a grainstone texture indicating that this facies was deposited in a high energy shoal/barrier environment (Tucker and Wright, 1990; Tucker et al., 2009). However, co-occurrence of ooids with porcelaneous foraminifera (miliolids and dendritina rangi) within a fine-grained matrix point to a relatively low energetic environment, indicating a textural inversion and redisposition. This means that after forming ooids in an energetic shoal environment, components were transferred to a low lagoonal setting (Warren, 2006; Flügel, 2010).

Reefal rudstone to boundstone (MF7)

This microfacies is characterized by coral of scleractinia or hexacorals together with red algae and large foraminifera especially acervulina sp. (Fig. 5G). Other components consist of very small skeletal debris and intraclasts occurring in a micritic matrix. They show a tightly packed fabric with poor sorting, as well as some framework porosity. These pores are usually filled by both calcite and evaporitic cement.

The depositional environment of this microfacies corresponds to the distal inner ramp that is situated above fair-weather wave base (FWWB). This interpretation is supported by the occurrence of coral rudstone (see Wilson, 1975 and Flügel, 2010). They are restricted to two samples which point to limited and a discontinuous distribution, likely forming patch reefs.

Bioclastic miliolid packstone (MF8)

This microfacies consists of a vast range of small benthic foraminifera especially miliolids (Fig. $5 \mathrm{H}$ ), making up a packstone. Calcareous algae like halimeda and dasycladacea as well as dendrita rangi foraminifera are poorly represented. Miliolid, dendritina packstone is recognized with beige to gray color and grainy texture. Skeletal allochems, porcelaneous foraminifers, specially miliolids and denderitina, are the main component of MF8. Additionally, echinoderms, bivalves and gastropods can be found. The fabric is grain-supported with relatively tight packing.

The depositional environment of this microfacies corresponds to the mid part of an inner ramp in the euphotic zone above fair-weather wave base. The occurrence of small to medium-sized porcelaneous foraminifera (miliolids) suggests an inner shelf environment (Geel 2000; Brandano and Corda 2003). Abundant allochems reflect a restricted lagoonal environment while gastropods indicate an open lagoon. The diversity and grain-supported fabric suggest higher hydrodynamic conditions than present in a restricted lagoon pinpointing to an open lagoonal environment.

Bioclastic echinoid wackestone (MF9) 
This microfacies is characterized by abundant echinoid fragments with intraclasts and rarely benthic foraminifera (Fig. 5I). It shows a poor sorting and loose packing. It is micrite matrix supported. In this microfacies vuggy pores are common and partially filled by cement.

The depositional environment of this microfacies corresponds to a lagoon within an inner ramp setting that is situated above fair-weather wave base. This interpretation is supported by the co-occurrence of echinoids evidencing open marine conditions with the small benthic foraminifera pointing to a more restricted environment (Flügel 2010). This microfacies differs from the former by its low diversity in skeletal grains.

Evaporites (MF10)

Evaporite phases are made up by laminated gypsum (Fig. 5K) displaying two main textures, namely alabastrine consisting of fine crystalline anhedral to subhedral crystals and porphyroblasts displaying coarse crystalline subhedral to euhedral crystals. Another texture that is infrequently observed, associated with the former, consists of daisywheel gypsum displaying rosette structures with needle gypsum crystals at their margins. There are some lath-shaped phases that usually correspond to pseudomorphs of anhydrite, especially occurring in the alabastrine textures.

According to Warren, (2006) the main evaporite settings are 1) mud flat evaporites with sabkha, saline pans and salinas, 2) salteran evaporites and 3) deep water evaporites. Absence of textures like nodular and chicken-wire evaporites that relate to mud flat evaporites within sabkha, saline pans and salinas suggest that such a setting did not existed in the study area. The first study thin layer of the evaporite called basal evaporite possibly precipitated in a deep water setting (Kavoosi and Sherkati, 2012; Rafiei and Rahmani, 2017). This explanation is based on the continues position of this evaporitic layer between deep water sediment of Pabdeh and Lower Asmari Formations. However, the main evaporite unit followed directly upon mid ramp deposits, intercalated with carbonate wackestones and mudstones that reflect a restricted environment. Furthermore, the presence of elongated nodular anhydrite (Fig. 8I) together with the lack of microfossils indicate a saltern environment within a shallow and restricted lagoon, an interpretation which is in line with Daraei et al. (2015).

Dolomitized mollusk wackestone with evaporites (MF11)

This microfacies is characterized by abundant micritized bivalves and high degree of matrix dolomitization (Fig. 5J). Other components are represented by micritic agglutinated foraminifera, ostracods, brachiopods and calcareous algae. It corresponds to a matrix-supported microfacies with tight packing. Vugs, intergranular and microfracture pore types are common. They are filled with dolomite and evaporite cements. Replacement of micrite by rhombohedral dolomite is the most common diagenetic feature in this microfacies.

The depositional environment of this microfacies corresponds to a restricted lagoon above fair weather wave base with poor connection to the open basin. Evidence for this interpretation relates to the low 
diversity in skeletal grains (Gadzicki, 1983; Wilson and Evans, 2002). In addition, the micritic matrix, the poorly sorting of intraclasts and good taphonomic preservation of brachiopods point to an environment with low-energy conditions.

Mudstone (MF12)

This microfacies is characterized by a mud-supported fabric containing irregular and amalgamated discontinuous fenestral pores and solution vugs (Fig. 5L). Partially to entirely pore-filling by blocky to granular evaporitic and dolomitic cement has been observed. Dolomitization is common forming rhombohedral crystals in the matrix.

The depositional environment of this microfacies corresponds to an intertidal flat and/or restricted lagoon. This interpretation is supported by well-preserved and widespread fenestral pore types which according to Hardie and Shinn (1986) originated from desiccation-shrinkage in an intertidal flat. Absence of skeletal grains also supports this interpretation.

\section{Sequence Stratigraphy Interpretation}

Based on field observations and petrography, both reflecting temporal and spatial changes in the microfacies that can be translated into sedimentary environments, together with petrophysical log data (gamma ray (GR) and sonic logs), the Asmari Formation in the two studied sections was subdivided into three depositional sequences (Fig. 6). These sequences reflect 1 to 10 million year corresponding to third order cycles. Each depositional sequence is characterized by a TST (transgressive systems tracts), HST (highstand systems tracts), with MFS (maximum flooding surface) and SB (sequence boundary).

Depositional sequence A (DS A)

Depositional sequence A, which is not well exposed, consists of thin layers of evaporite and thick and thin bedded limestones in the Syah-koh section and thin layers of evaporite as well as marl and thick bedded limestone in well A. The thickness of this sequence is respectively about 50 and $53 \mathrm{~m}$. The only system tract recognized in this depositional sequence is a HST. The TST more likely is preserved in the underlying Pabdeh Formation since a depositional deepening for this formation is assumed when compared to Asmari (Vaziri-Moghaddam et al., 2010).

The maximum GR log response along with the low response of the sonic log at the lower part of "DS A" indicates a $2 \mathrm{~m}$ thick evaporite that continues in a $4 \mathrm{~m}$ thick shale layer which marks the boundary between the Asmari and Pabdeh Formation in well A. This can be correlated with the sharp transition of the thin bedded evaporite of Asmari Formation to olive marls in the lower Asmari Formation interval in the Syah-koh section (Fig. 6).

The HST of this DS mainly includes mid ramp deposits in the Syah-koh section with low API in the GR log and also the transition of shale to anhydrite layers of the Kalhor Member at the end of this sequence reflecting a shallowing upward trend in well-A (Fig. 6). The upper boundary of this DS is located at the 
base of an anhydrite succession in the Syah-koh section and well-A which reflects a restricted lagoonal environment that developed in an inner shelf setting.

\section{Depositional sequence B (DS B)}

Depositional sequence $\mathrm{B}$, comprising thin anhydrite layers with occasional dolomites and thick bedded limestones in both study locations correspond to the Kalhor Member (Fig. 6). The thickness of this sequence in the Syah-koh section and in the well-A was about 100 and $50 \mathrm{~m}$, respectively. It should be noted that the distinct difference in thickness of the Kalhor Member is due to presence of halite and anhydrite in well-A. The lower sequence boundary, marked by anhydrite sediments was already mentioned and the upper sequence boundary corresponds to restricted lagoonal deposits in both sections (Fig. 6). The TST of "DS B" consists of restricted lagoonal deposits in the two studied sections while the maximum flooding surface (MFS) consists of open lagoonal deposits. In addition, the TST possesses increasing clay content and an increase of the GR log together with decreasing values in the sonic log. The HST deposition reveals open to restricted lagoon environment. The end of the anhydrite succession (Kalhor Member) can be considered as SB and "DS B". Besides, during this DS the strata show an aggradational stratal pattern and an increase in dolomite content.

Depositional sequence C (DS C)

Depositional Sequence C primarily comprises thick bedded limestones in the Syah-koh section and in well-A. Its thickness varies around 120 and 100 m, respectively. The lower and upper sequence boundary is marked by anhydrite sediments in both sections (Fig. 6). The TST of this DS consists of sediments deposited in an open lagoon in Syah-koh section and in a mid-ramp setting in well-A. MFS of "DS C" in well-A is characterized by mid-ramp microfacies along with high API values in the GR log reflecting an increase in clay content, and it is represented by mid ramp deposits in the Syah-koh section (Fig. 6). The shallowing upward trend of the HST in this sequence is characterized by medium to thick bedded limestone reflecting mid and inner ramp depositional environment in the Syah-koh section and in the wellA.

\section{Diagenesis And Paragenesis}

The main diagenetic features observed in the studied Asmari intervals include micritization, cementation, dissolution (porosity development), dolomitization, physical and chemical compaction, and fracturing.

Micritization is evident as micritic envelopes around skeletal fragments. The most pervasive calcite cement types are isopachous fibrous, drusy mosaic, dogtooth, granular, veins-filled and blocky cements. All the cements, except for the blocky ones which show bright CL colours, are dull when viewed under cathodoluminescence (Fig. 7A to G). Evaporitic cements (gypsum) were also observed in the study area (Fig. $7 \mathrm{H}, 8 \mathrm{G}$ and $\mathrm{H}$ ). The thickest dolomitization interval occurs as an interlayer within the Kalhor Member (reflecting restricted lagoon settings). These dolomites include fine to medium euhedral crystals (100$200 \mu \mathrm{m}$ ) with lilac CL colour (Fig. 7L and M) and saddle dolomite. In the carbonate section of the Upper 
Asmari, dolomitization occur as replacement phases as well as cement (Fig. 8A to C). Physical compaction and stylolitisation are other diagenetic features that can be recognized in the studied area (Fig. 8D to F). Moreover, microfractures filled by veins (both calcite and evaporite) also occur widespread mainly in matrix support intervals like mudstone (Fig. 7D to $\mathrm{H}$ and 8E). The dissolution observed in the study area consist of moldic, vuggy and enlarged inter- and intragranular porosity. Moldic porosity is most probably caused by the aragonitic nature of skeletal grains and the vuggy porosity usually is often produced by enlargement of moldic porosity during different stages of the diagenesis (Fig. $7 \mathrm{I}$ to $\mathrm{K}$ ). Enlarged intragranular caused by dolomitization which is common in the study area is very apparent in carbonate interlayers of the Kalhor Member. Based on these features the paragenesis (Fig. 9) can be split up into three different diagenetic settings: i.e. marine, meteoric, and burial realms.

\section{Stable Carbon And Oxygen Isotopes}

Stable isotope analyses were performed on micrite and cements. The obtained values are shown in Table 1 and plotted in Fig. 10. Micrite samples show $\delta^{13} \mathrm{C}$ values ranging from -7.73 to $+2.49 \%$ ond $\delta^{18} O_{V-P D B}$ values ranging between -9.18 to $+1.77 \%$ o. The slightly higher stable isotope values of both carbon and oxygen in the study area when compared to reported Oligo-Miocene marine carbonates (e.g. Vandenberghe et al., 2012) can be explained by marine dolomitization that widely affected the Asmari limestones. Cements show a range in $\delta^{18} \mathrm{O}_{V-P D B}$ and $\delta^{13} \mathrm{C}$ values varying between -9.82 and $-0.43 \%$ and from -15.35 to $+0.98 \%$ o respectively. The majority of $\delta^{18} \mathrm{O}$ and $\delta^{13} \mathrm{C}$ values in cements represent an overall shift towards depleted values when compared to the micrites. The most depleted $\delta^{18} \mathrm{O}_{\mathrm{V}-\mathrm{PDB}}(-8.25$ and $-9.18 \%$ ) and $\delta^{13} \mathrm{C}(-7.73$ and $-2.64 \%$ ) values in micrites were detected in the limestone interlayers of the Kalhor Member. Furthermore, Total Organic Carbon (TOC) of 19 micrite samples ranges from 0.08 to $4.3 \%$. The total organic matter content is, however, low, indicating an oxygenated setting which altered most of the organic matter. The $\delta^{13} \mathrm{C}$ values of TOC vary between -26.5 to $-11.1 \%$ o.

\section{Discussion}

\section{Depositional environment}

The 12 microfacies are interpreted to have been deposited in a broad ramp-type setting following the criteria presented by Buxton and Pedley (1989), Wilson (2002) and Flügel (2010). The reconstructed paleo-depositional environment is depicted in Fig. 11. This depositional system started with an outer ramp (deep water) where pelagic microfacies accumulated and gradually evolved into an extended mid ramp where large benthic foraminifera, coral and red algae (e.g. Peyssoneliacean) accumulated to form grain- and rudstones. The subsequent changes reflect an evolution towards open lagoon to mid ramp depositional settings as reflected by the occurrence of large and small benthic foraminifera and red algae. These depositional settings evolved into a restricted lagoon with noticeable decrease in fauna diversity on the one hand and deposition of evaporites on the other hand. The restricted lagoon eventually evolved into an intertidal setting marked by fenestral porosity and vadose cements. Among the 
samples studied from the Siah-koh Anticline and well-A, it appears that coral boundstone only occur in the subsurface well, whereas, large foraminifera especially operculina is more common in the outcrop section (i.e. Siah-koh Anticline). Most importantly, the deposits studied in the aforementioned two sections show obvious differences in thickness of evaporites due to presence of thick halite packages in well-A. This indicates that the basin system became more enclosed away from the more open marine Siah-koh Anticline in direction to well A. Moreover, according to Jahani et al. (2007) salt mobility occurs due to salt tectonics causing the movement of salt from syncline to anticline. Accordingly, as well-A was drilled in an anticlinal structure this explains to some degree the thickness differences caused by salt movements.

\section{Diagenetic evolution}

Early marine diagenesis started in the studied intervals with micritization of bioclasts (e.g. Macintyre et al., 2000; Reid and Macintyre, 2000; Swei and Tucker, 2012). The micritic envelope and entire micritization especially affected open and restricted lagoonal strata. Moreover, due to saline water containing vast amounts of Mg, the condition to precipitate dolomite was facilitated especially in Kalhor Member carbonates. Another early diagenetic modification appeared as isopachous fibrous fringing cements formed around the grains (Okubo et al., 2015). These cements are mostly observed within open lagoon and shoal microfacies with active circulating water. The presence of mosaic, dogtooth and equant cements as well as dissolution following marine cements likely point to meteoric diagenesis as the result of an exposure period. Late diagenesis occurred during burial as evidenced by saddle dolomitization, physical compaction and pressure dissolution (stylolitization). Mechanical compaction between grains is observed in grain-supported strata of mid ramp, shoal and open lagoon, while chemical compaction is manifested by occurrence of solution seams and stylolite, especially in outer ramp strata. Thus, it can be concluded that diagenesis is not uniform over this formation and influenced the strata differently based on its composition (components and matrix) and emergence hiatus of Asmari Formation in Lorestan basin. The best reservoir intervals can be found in outer ramp carbonates that have widespread microfractures, due to its micritic dominance with limited diagenetic influence, and some in dolomitized lithologies together with lagoonal deposits with the vast development of dolomitization. Moreover, the limited shoal deposits containing ooids that experienced dissolution also can be considered as one of the best reservoir intervals.

According to Choquette and James (1987), a large distribution of the $\delta^{18} O$ values (as reported in this study) suggests different diagenetic environments including marine, meteoric and burial as also reflected in the petrography of the studied samples. Cements with $\delta^{18} \mathrm{O}_{V-P D B}$ values between -2 and $0 \%$ o suggest precipitation under marine conditions. This interpretation is in agreement with the non-luminescent characteristics of the fibrous cements (see Fig. 7F). The observed $J$ trend (negative $\delta^{13} \mathrm{C}$ and $\delta^{18} \mathrm{O}$ ) in the isotope cross plot of the cements (Fig. 11A) most likely point to the near-surface influence of meteoric waters (Allan and Matthews, 1982; Lohmann, 1988). This can be related to organic matter resulting from soil $\mathrm{CO}_{2}$ caused by karst related phenomena or soil formation which is typical for eogenetic conditions. 
Besides, it also can originate from oil and methane oxidation, however, then normally the $\delta^{13} \mathrm{C}$ values are much more negative. Further evidences testifying to such eogenetic realm is the presence of concentric non-bright-dull CL zonation of the cement (see Fig. $7 C$ ). The most depleted $\delta^{18} \mathrm{O}_{V \text {-PDB }}$ values of cements as low as $-10 \%$ may reflect precipitation or recrystallization from fluids with elevated temperatures under burial conditions (Choquette and James, 1987). This is in line with petrographic data showing uniform bright luminescence in blocky calcite (see Fig. 7G). Notably, the samples with almost the same ranges of stable isotope in both cement and micrite showing also a relatively high concentration of TOC suggest extensive recrystallization.

\section{Conclusions}

Twelve major microfacies reflecting the gradual transition from open marine to shore and lagoonal settings were identified in two sections crosscutting the Asmari Formation. Absence of extended reefal structures and/or indication of deep marine settings as well as microfacies characteristics shows that the studied carbonates developed on a broad low angle carbonate ramp. Initial sedimentation started in an open-marine outer ramp setting. This depositional setting evolved successively into a moderate energy mid ramp setting and an inner ramp characterized by the presence of large benthic foraminifera and local patches of reefs, respectively. The inner ramp setting developed into an open lagoon and restricted lagoon with evaporitic deposits evolved into an intertidal environment with dolomitic deposits and widespread occurrence of fenestral fabrics. The thick evaporitic deposits (50 m; Kalhor Member) corresponding to the middle part of the Asmari Formation indicates a restricted and shallower environment for this part of Zagros Basin relative to other parts.

Three third-order depositional sequences were deduced based on lithology, Gamma-ray and sonic log reflecting deepening and shallowing trends in the depositional environment of the studied area. The depositional patterns observed in these sequences suggest the deepening of the basin from well-A (oilfield located at the western part of the Lorestan Basin) towards the Syah-koh Anticline.

The diagenetic modifications include early (marine and meteoric) and late (burial) diagenesis constrained by petrography and $\delta^{13} \mathrm{C}$ and $\delta^{18} \mathrm{O}$ values. The best reservoir intervals are the carbonates deposited in outer ramp and lagoonal settings. Finally, the outer ramp with widespread open microfractures, shoal with ooids as well as lagoonal deposits that experienced dolomitization can consider as the best reservoir intervals.

\section{Declarations}

\section{Acknowledgements}

This research was performed by collaboration between Shahid Beheshti and KU Leuven universities in the framework of a research project funded by Iranian National oil company (NIOC). The authors are grateful to Prof. Dr. ir. S. Bouillon and colleagues of the Department of Earth and Environmental Sciences of the 
KU Leuven (Belgium) for performing the oxygen and carbon stable isotope measurements. We gratefully acknowledge Ms. Z. Saleh for her helpful suggestions for sequence stratigraphy.

\section{References}

1. Adabi MH, Kakemem U, Sadeghi A (2016) Sedimentary facies, depositional environment, and sequence stratigraphy of Oligocene-Miocene shallow water carbonate from the Rig Mountain, Zagros basin (SW Iran). Carbonates evaporites 31:69-85

2. Alavi M (1980) Tectonostratigraphic evolution of the Zagrosides of Iran. Geology 8(3):144-149

3. Alavi M (2007) Structures of the Zagros fold-thrust belt in Iran. American Journal of science 307(9):1064-1095

4. Allan JR, Matthews RK (1982) Isotope signatures associated with early meteoric diagenesis. Sedimentology 29(6):797-817

5. Berberian M, King GCP (1981) Towards a paleogeography and tectonic evolution of Iran. Can J Earth Sci 18:210-265

6. Busk HG, Mayo HT (1918) Some notes on the geology of the Persian Oilfields. Journal Institute Petroleum Technology 5:5-26

7. Buxton MWN, Pedley HM (1989) Short Paper: A standardized model for Tethyan Tertiary carbonate ramps. J Geol Soc 146(5):746-748

8. Catuneanu O (2006) Principles of sequence stratigraphy. Elsevier, 375 pp

9. Choquette PW, James NP (1987) Diagenesis 12: Diagenesis in limestones: 3. The deep burial environment: Geoscience Canada, 14, 3-35

10. Ćosović V, Drobne K, Moro A (2004) Paleoenvironmental model for Eocene foraminiferal limestones of the Adriatic carbonate platform (Istrian Peninsula). Facies 50(1):61-75

11. Corda L, Brandano M (2003) Aphotic zone carbonate production on a Miocene ramp, Central Apennines, Italy. Sed Geol 161(1-2):55-70

12. Daraei M, Amini A, Ansari M (2015) Facies analysis and depositional environment study of the mixed carbonate-evaporite Asmari Formation (Oligo-Miocene) in the sequence stratigraphic framework, NW Zagros, Iran. Carbonates evaporites 30(3):253-272

13. Dickson J (1965) A modified staining technique for carbonates in thin section. Nature 205:587-587

14. Dill MA, Seyrafian A, Vaziri-Moghaddam H (2010) The Asmari Formation, north of the Gachsaran (Dill anticline), southwest Iran: facies analysis, depositional environments and sequence stratigraphy. Carbonates Evaporites 25(2):145-160

15. Dunham RJ (1962) Classification of carbonate rocks according to depositional textures

16. Falcon NL (1961) Major earth-flexuring in the Zagros Mountains of south-west Iran. Quarterly Journal of the Geological Society 117(1-4):367-376 
17. Falcon NL (1974) Southern Iran: Zagros Mountains. Geological Society, London, Special Publications, 4(1), 199-211

18. Farhoudi G (1978) A comparison of Zagros geology to island arcs. J Geol 86(3):323-334

19. Flugel E (2010) Microfacies of carbonate rocks, analysis, interpretation and application. SpringerVerlag, New York

20. Geel T (2000) Recognition of stratigraphic sequences in carbonate platform and slope deposits: empirical models based on microfacies analysis of Palaeogene deposits in southeastern Spain. Palaeogeogr Palaeoclimatol Palaeoecol 155(3-4):211-238

21. Gharechelou S, Amini A, Kadkhodaie-llkhchi A, Moradi B (2015) An integrated approach for determination of pore-type distribution in carbonate-siliciclastic Asmari Reservoir, Cheshmeh-Khosh Oilfield, SW Iran. J Geophys Eng 12(5):793-809

22. Gharechelou S, Daraei M, Amini A (2016) Pore types distribution and their reservoir properties in the sequence stratigraphic framework: a case study from the Oligo-Miocene Asmari Formation, SW Iran. Arab J Geosci 9(3):194

23. Gharechelou S, Amini A, Kadkhodaei A, Hosseini Z, Honarmand J (2018) Rock typing and reservoir zonation based on the NMR logging and geological attributes in the mixed carbonate-siliciclastic Asmari Reservoir. Geopersia 8(1):77-98

24. Ghavidel-Syooki M (1995) Palynostratigraphy and palaeogeography of a Palaeozoic sequence in the Hassanakdar area, Central Alborz Range, northern Iran. Rev Palaeobot Palynol 86(1-2):91-109

25. Gadzicki A (1983) Foraminifers and biostratigraphy of Upper Triassic and Lower Jurassic of the Slovakian and Polish Carpathians. Palaeont Polon 44:109-169

26. Haq BU, Al-Qahtani V (2005) Jurassic-Neogene Arabian Platform Cycle Chart GeoArabia 10:34 p

27. Hardie LA, Shinn EA (1986) Carbonate depositional environments: modern and ancient. III: Tidal flats. Colorado School of Mines Quarterly, 81(1)

28. Hosseini, Z., Gharechelou, S., Nakhaei, M. and Gharechelou, S., 2016. Optimal design of BP algorithm by ACOR model for groundwater-level forecasting: A case study on Shabestar plain, Iran. Arabian Journal of Geosciences, 9, 436, 16 p.

29. Jahani S, Callot JP, de Lamotte DF, Letouzey J, Leturmy P (2007) The salt diapirs of the eastern Fars Province (Zagros, Iran): A brief outline of their past and present. In: Thrust Belts and Foreland Basins. Springer, Berlin, pp 289-308

30. Kashfi MS (1976) Plate tectonics and structural evolution of the Zagros geosyncline, southwestern Iran. Geol Soc Am Bull 87(10):1486-1490

31. Kavoosi MA, Sherkati S (2012) Depositional environments of the Kalhor Member evaporites and tectonosedimentary evolution of the Zagros fold-thrust belt during Early Miocene in south westernmost of Iran. Carbonates Evaporites 27(1):55-69

32. Lohmann KC (1988) Geochemical patterns of meteoric diagenetic systems and their application to studies of paleokarst. In: Paleokarst. Springer, New York, pp 58-80 
33. Macintyre IG, Prufert-bebout L, Reid RP (2000) The role of endolithic cyanobacteria in the formation of lithified laminae in Bahamian stromatolites. Sedimentology 47:915-921

34. Mohammadi Z, Claes H, Capezzuoli E, Mozafari M, Soete J, Aratman C, Swennen R (2019) Lateral and vertical variations in sedimentology and geochemistry of subhorizontal laminated travertines (Çakmak quarry, Denizli Basin, Turkey), Quaternary International: https://doi.org/https://doi.org/10.1016/j.quaint.2018.11.041

35. Motiei H (1993) Stratigraphy of Zagros. In: Treatise on the geology of Iran. No. 1. Ministry of Mines and Metals. Geological Society of Iran Publications, Tehran (in Persian)

36. Motiei H (2001) Simplified Table of rock unit in southwest Iran (a map unpublished, KEPS Company)

37. Pedley HM,. (Eds VP, Wright, Burchette TP (1998) A review of sediment distributions and processes in Oligo-Miocene ramps of southern Italy and Malta (Mediterranean divide). In: Carbonate Ramps. Geol Soc London Spec Publ 149:163-179

38. Rafiei B, Rahmani S (2017) Textural pattern of secondary gypsum in the Basal Anhydrite of the Asmari Formation. SW Iran Geopersia 7(2):267-278

39. Rahmani A, Vaziri-Moghaddam H, Taheri A, Ghabeishavi A (2009) A model for the paleoenvironmental distribution of larger foraminifera of Oligocene-Miocene carbonate rocks at Khaviz Anticline, Zagros Basin, SW Iran. Hist Biol 21(3-4):215-227

40. Rasser MW (2000) Paleoecology and Taphonomy of Polystrata alba (red algae) from the Late Eocene Alpine Foreland: a new tool for the reconstruction of sedimentary environments. Palaios 16(6):601-607

41. Rasser MW, Nebelsick JH (2003) Provenance analysis of Oligocene autochthonous and allochthonous coralline algae: a quantitative approach towards reconstructing transported assemblages: Palaeogeography, Palaeoclimatology. Palaeoecology 201(1):89-111

42. Reid RP, Macintyre IG (2000) Microboring versus recrystallization: Further insight into the micritization process. J Sediment Res 70:24-28

43. Romero J, Caus E, Rosell J (2002) A model for the palaeoenvironmental distribution of larger foraminifera based on late Middle Eocene deposits on the margin of the South Pyrenean basin (NE Spain): Palaeogeography, Palaeoclimatology. Palaeoecology 179(1):43-56

44. Seyrafian A (2000) Microfacies and depositional environments of Asmari Formation at Dehdez area (a correlation across Central Zagros Basin). Carbonates Evaporites 15:22-48

45. Seyrafian A, Hamedani A (1998) Microfacies and depositional environment of the upper Asmari Formation (Burdigalian), north-central Zagros Basin, Iran. Neues Jahrbuch für Geologie und Paläontologie-Abhandlungen, 129-141

46. Seyrafian A, Hamedani A (2003) Microfacies and paleoenvironmental interpretation of the Lower Asmari Formation (Oligocene), North-Central Zagros Basin, Iran. Neues Jahrbuch für Geologie und Paläontologie, 3, 164-167

47. Sadeghi R, Vaziri-Moghaddam H, Taheri A (2011) Microfacies and sedimentary environment of the Oligocene sequence (Asmari Formation) in Fars sub-basin, Zagros Mountains, southwest Iran. Facies 
57(3):431-446

48. Stöcklin J (1974) Possible ancient continental margins in Iran. In: The geology of continental margins, Springer, 873-887 p

49. Swei GH, Tucker ME (2012) Impact of diagenesis on reservoir quality in ramp carbonates: Gialo Formation (Middle Eocene), Sirt Basin, Libya. J Pet Geol 35(1):25-47

50. Tucker ME, Wright VP (1990) Carbonate Sedimentology. Blackwell Science, Oxford, 482 pp

51. Tucker ME, Gallagher J, Leng MJ (2009) Are beds in shelf carbonates millennial-scale cycles? An example from the mid-Carboniferous of northern England. Sed Geol 214(1-4):19-34

52. Ogg JG, Ogg GM, Gradstein FM (2016) A Concise Geologic Time Scale. Elsevier, 229 p

53. Okubo J, Lykawka R, Warren LV, Favoreto J, Dias-Brito D (2015) Depositional, diagenetic and stratigraphic aspects of Macaé Group carbonates (Albian): example from an oilfield from Campos Basin. Brazilian Journal of Geology 45(2):243-258

54. Van Buchem FSP, Allan TL, Laursen GV, Lotfpour M, Moallemi A, Monibi S, Motiei H, Pickard NAH, Tahmasbi AR, Vedrenne V, Vincent B (2010) Regional stratigraphic architecture and reservoir types of the Oligo-Miocene deposits in the Dezful Embayment (Asmari and Pabdeh Formations) SW Iran. Geological Society, London, Special Publications, 329(1), 219-263

55. Vandenberghe N, Hilgen FJ, Speijer RP (2012) The Geologic Time Scale 2012

56. Vaziri-Moghaddam H, Kimiagari M, Taheri A (2006) Depositional environment and sequence stratigraphy of the Oligo-Miocene Asmari Formation in SW Iran. Facies 52(1):41-51

57. Vaziri-Moghaddam H, Seyrafian A, Taheri A, Motiei H (2010) Oligocene-Miocene ramp system (Asmari Formation) in the NW of the Zagros basin, Iran: Microfacies, paleoenvironment and depositional sequence. Revista Mexicana de Ciencias Geológicas 27(1):56-71

58. Warren JK (2006) Evaporites: sediments, resources and hydrocarbons. Springer, p 1035

59. Wilson ME (2002) Cenozoic carbonates in Southeast Asia: implications for equatorial carbonate development. Sed Geol 147(3-4):295-428

60. Wilson JL (1975) Carbonate Facies in Geologic History: New York, N.Y., Springer-Verlag, 470 p

\section{Figures}




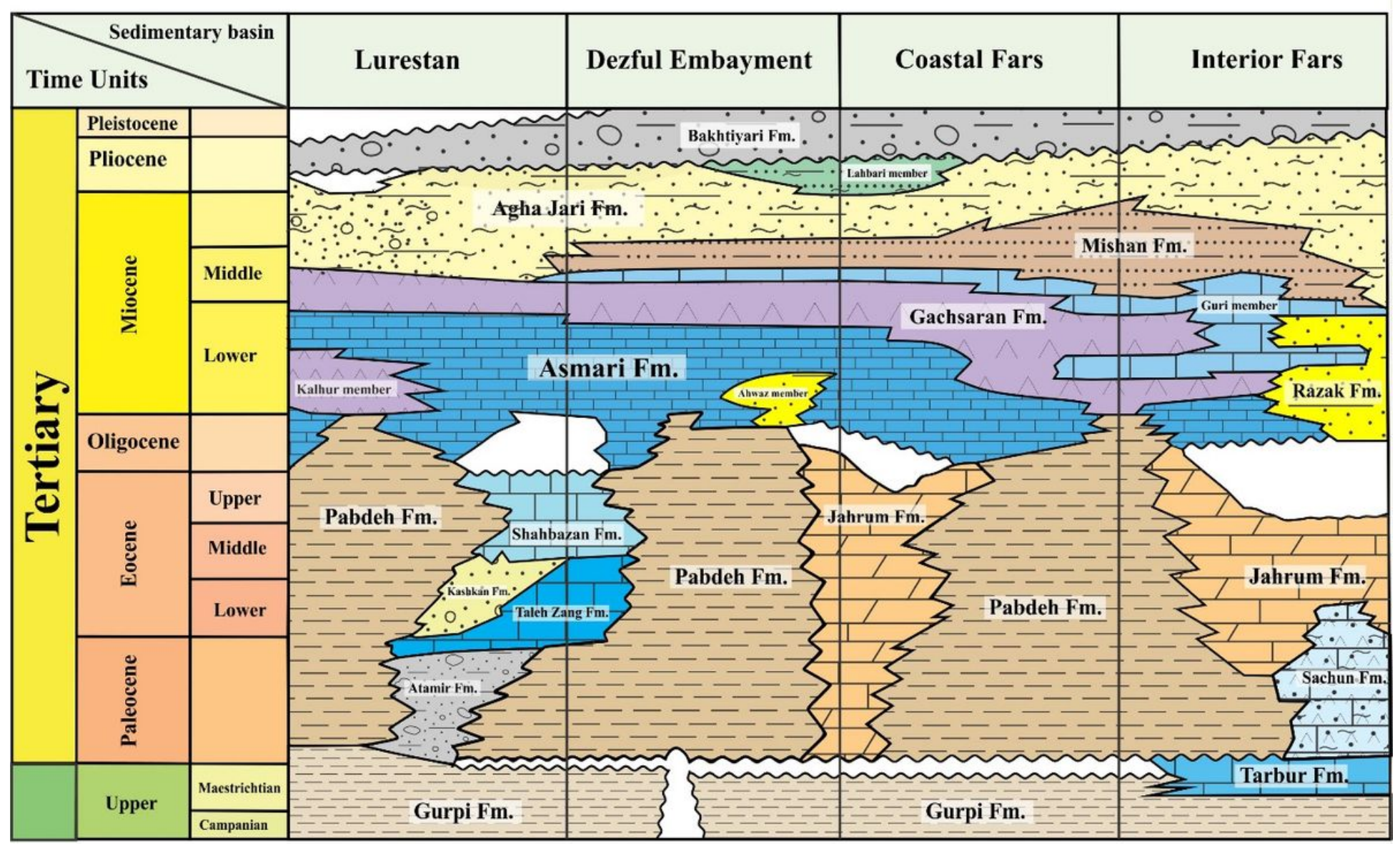

\section{Figure 1}

Stratigraphic column showing the distribution of the Asmari Formation and other formations during the Cenozoic in Zagros basin (Iran) (modified from Motiei, 2001). 


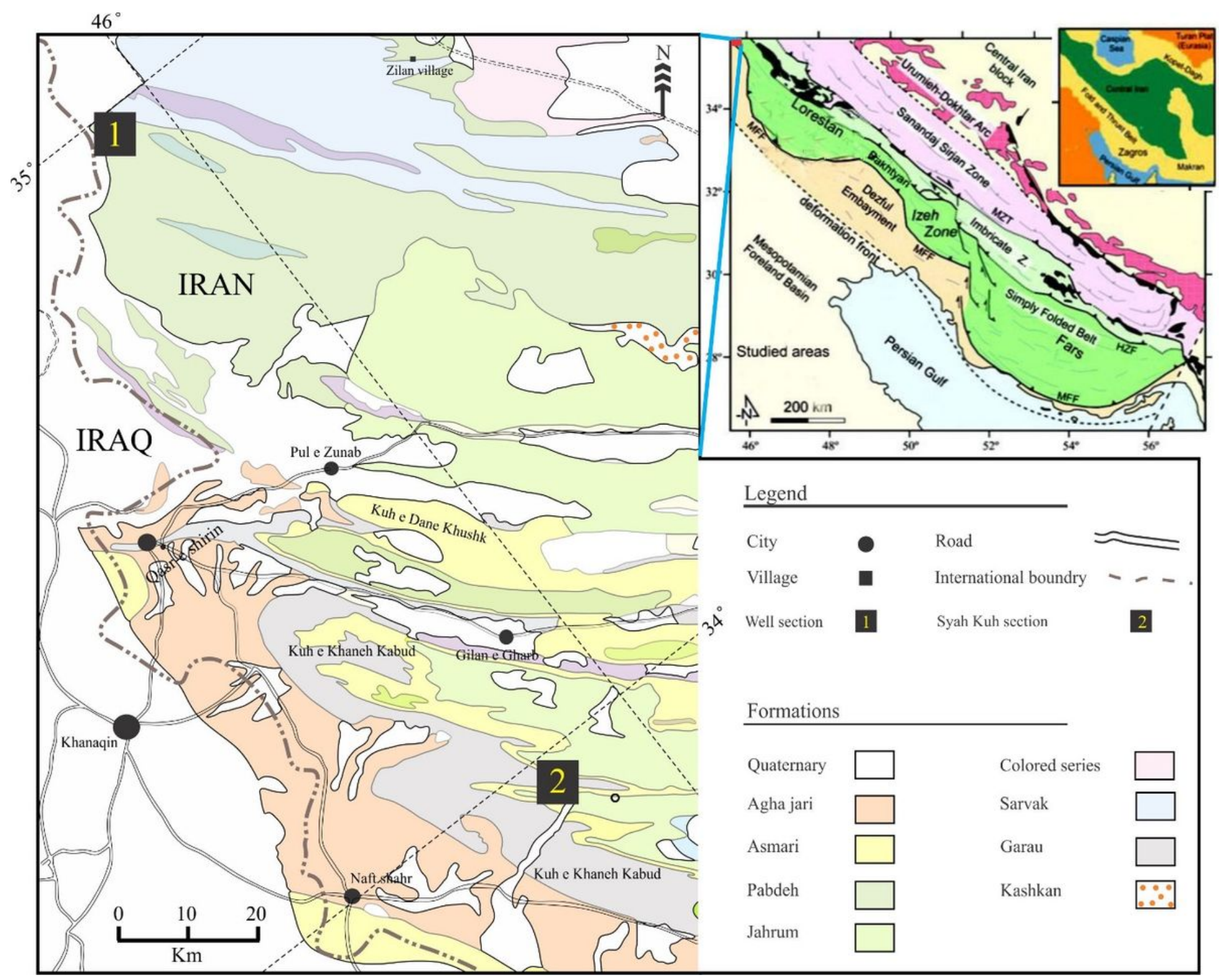

Figure 2

Geological map showing the location of the studied areas in western Iran (after National Iranian Oil Company). In the left map of Iran together with subdivisions of the Zagros in Iran (after Khorassani et al., 2015). The reed rectangle (in the northwestern part of the left picture) shows the position of studied area. 

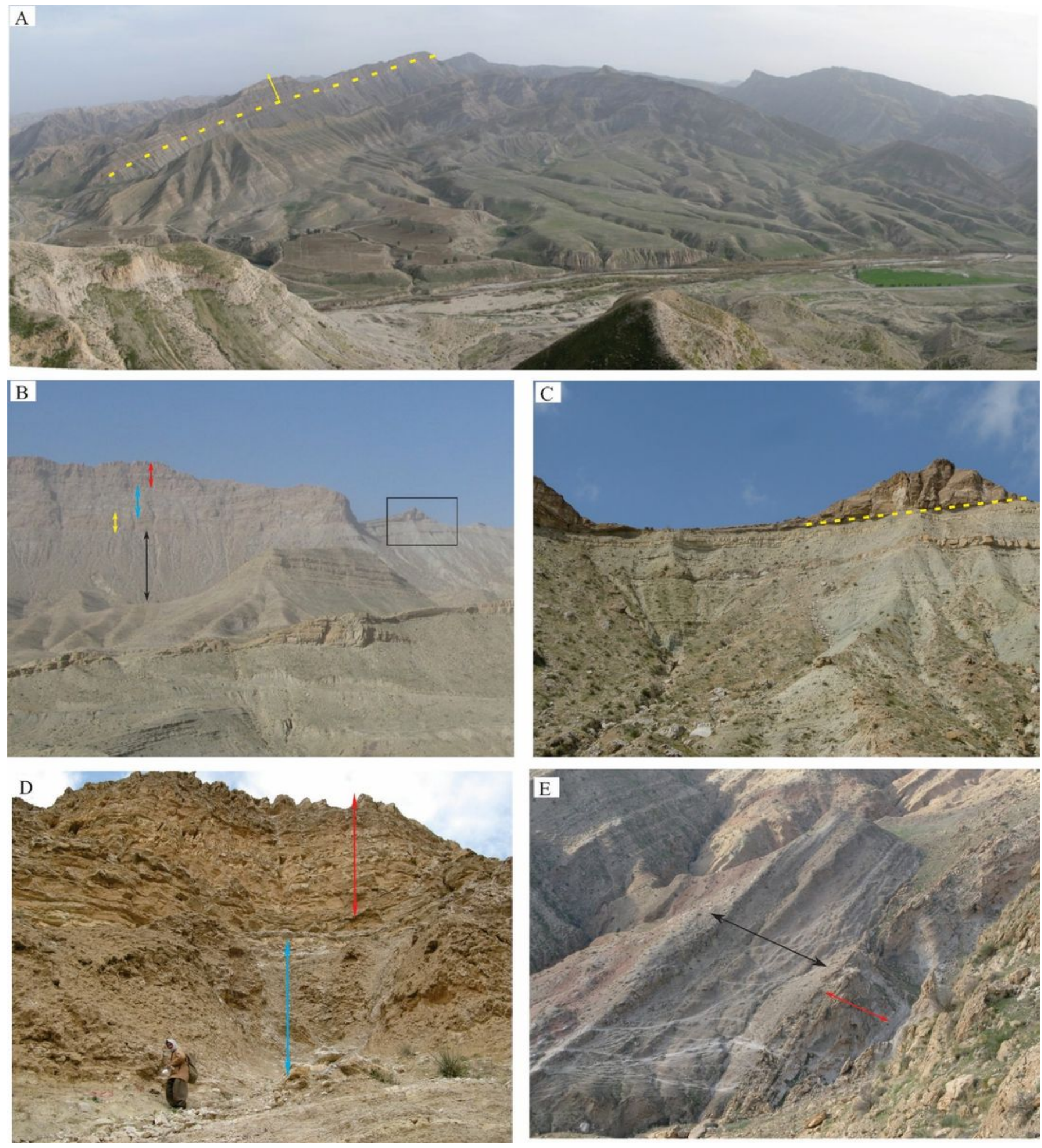

\section{Figure 3}

Field photograph of Asmari Formation. A) Field view of the Syah-Koh Anticline (yellow line shows a border between Asmari and Pabdeh Formation and yellow arrow shows the Asmari Formation. B) Succession of Pabdeh Formation (black arrow), lower Asmari (yellow arrow), Kalhor Member (blue arrow) and upper Asmari (red arrow). Black rectangle indicates the area of C. C) Close view of contact between 
Pabdeh and Asmari Formation. D) Close view of the Kalhor Member (blue arrow) and upper Asmari (red arrow). E) Upper Asmari (red arrow) and overlying Gachsaran Formation (black arrow).
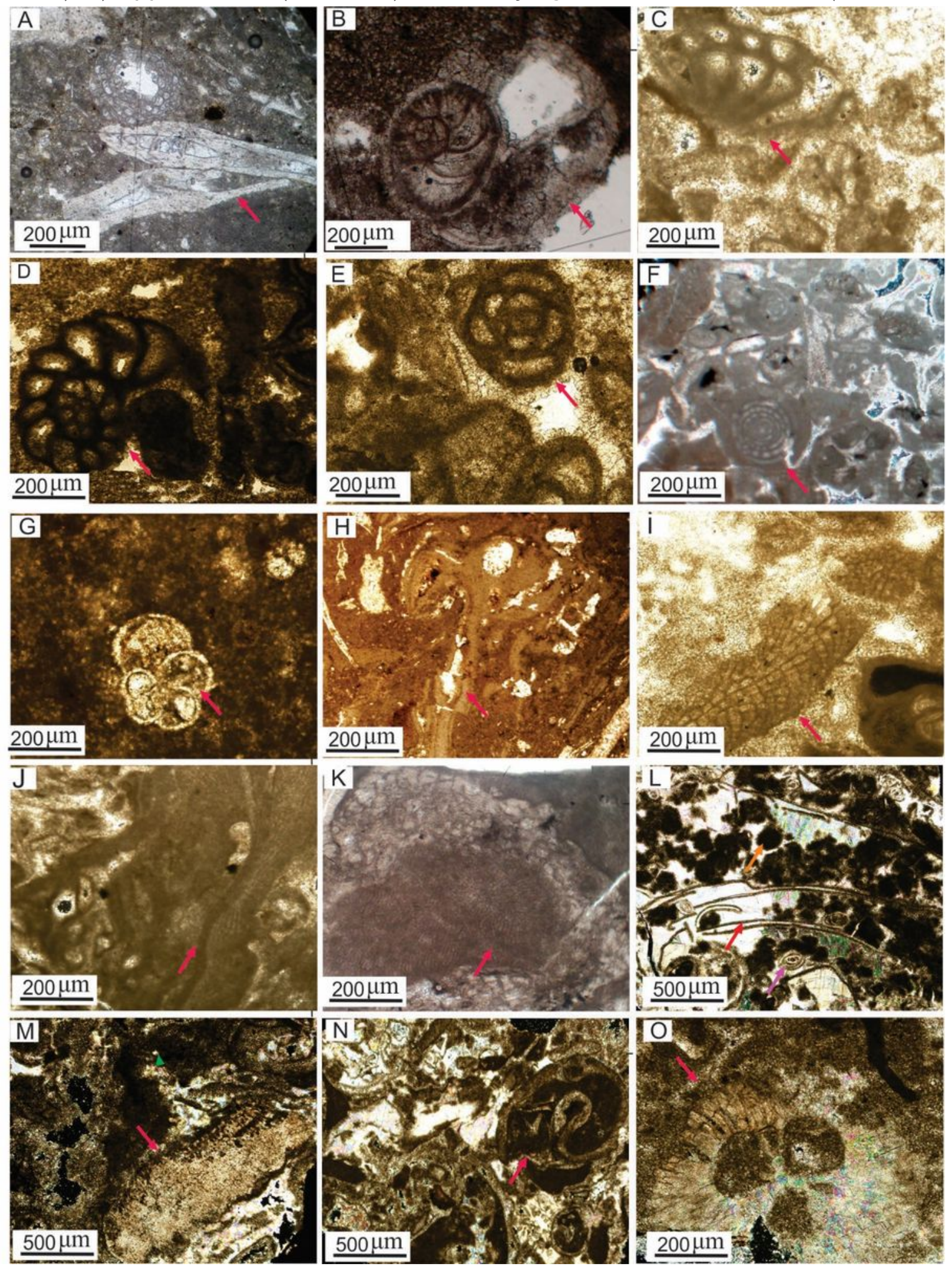

\section{Figure 4}

Microphotographs of different skeletal grains in Asmari Formation (indicated by red arrow). A) Operculina foraminifera; B) Elphidum sp. foraminifera; C) Archaias sp, foraminifera; D) Dendritina rangi foraminifera; E) Miliolids foraminifera; F) Borelis Melocurdina foraminifera; G) Globigerinids planktonic foraminifera; 
H) Peyssoneliacean red algae I) Subterraniphyllum sp. red algae; J) Lithophyllum red algae; K) Encrusting of Acervulina foraminifera with red algae; L) Peloid trapped in pelecypods; M) Echinoid; N) Gastropod; O) Bryozoans Tubocelaria.
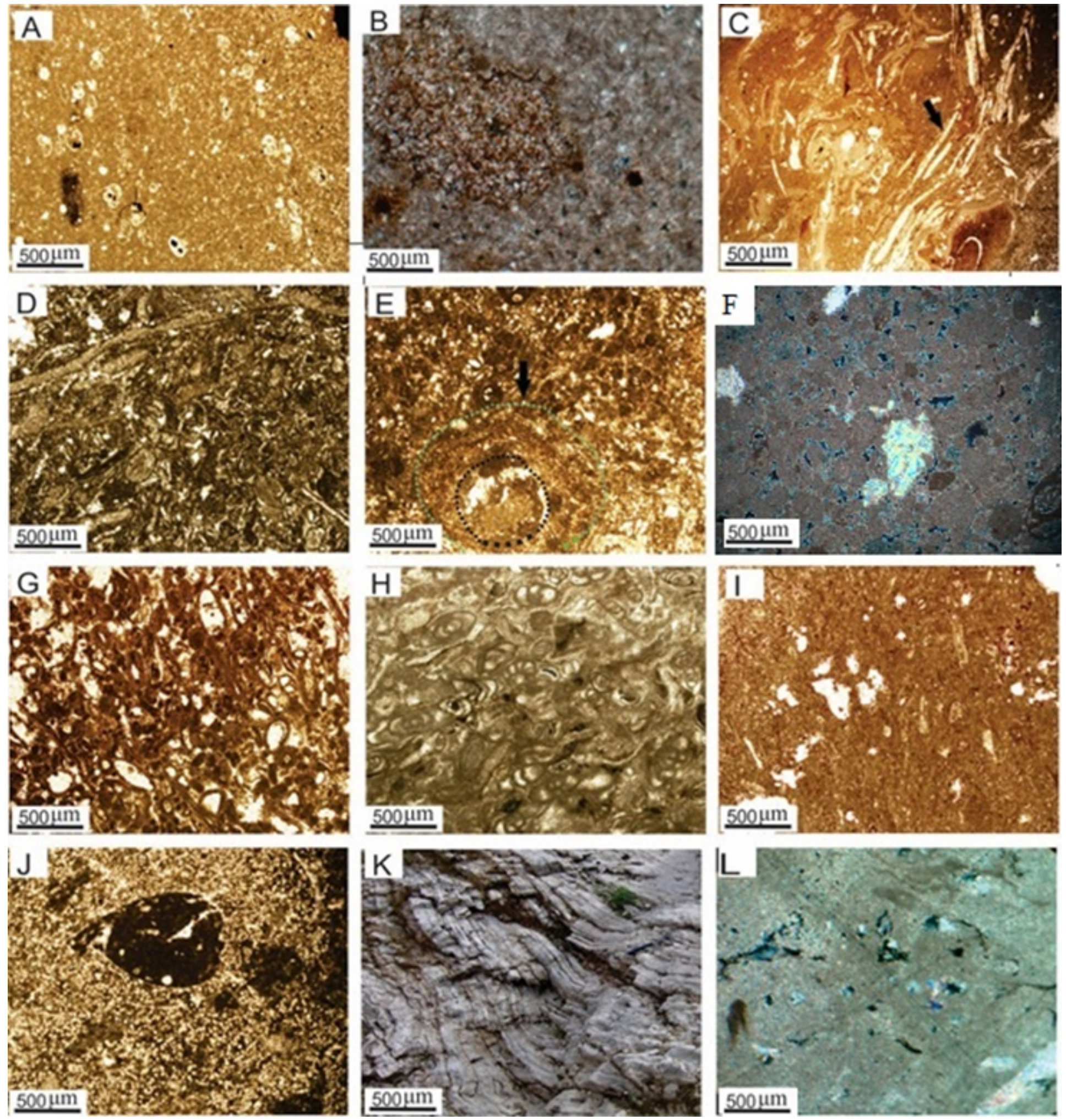

Figure 5

Microphotographs of different microfacies of Asmari Formation. A) Planktonic foraminifera wackestone; B) Bioclastic mudstone; C) Operculina algal packstone/rudstone; D) Bioclastic bindstone; E) Oncoidal 
peloidal pack- to grainstone; F) Bioclastic and ooid grainstone; G) Large benthic foraminifera packstone/rudstone; $\mathrm{H}$ ) Bioclastic miliolid packstone; I) Bioclastic echinoid wackestone; J) Dolomitized mollusk wackestone with evaporites; K) Laminated evaporites; L) Mudstone.

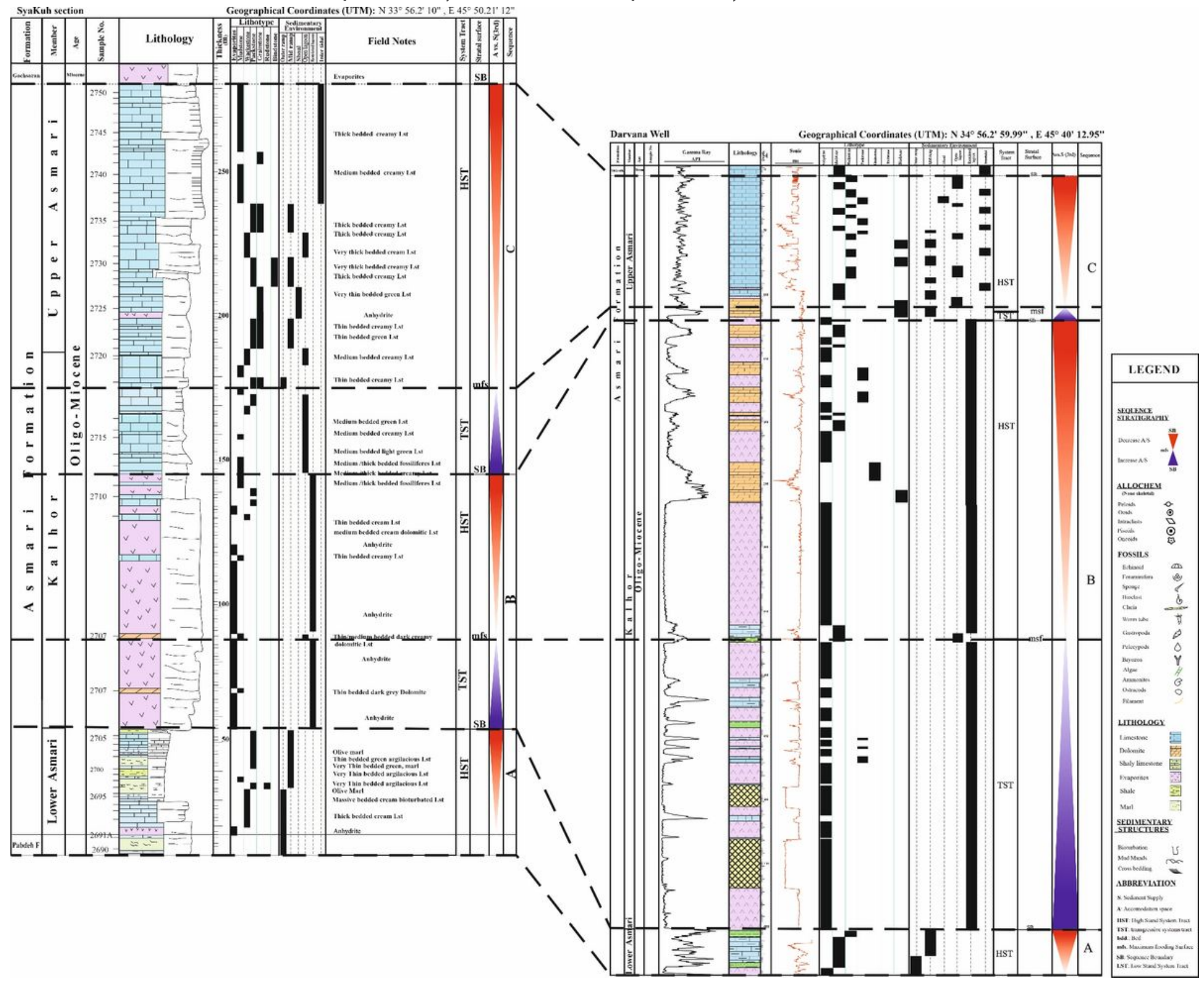

Figure 6

Lithology, texture (lithotype), sedimentary environment and sequences (3rd) of Asmari Formation in the studied outcrop and well. 

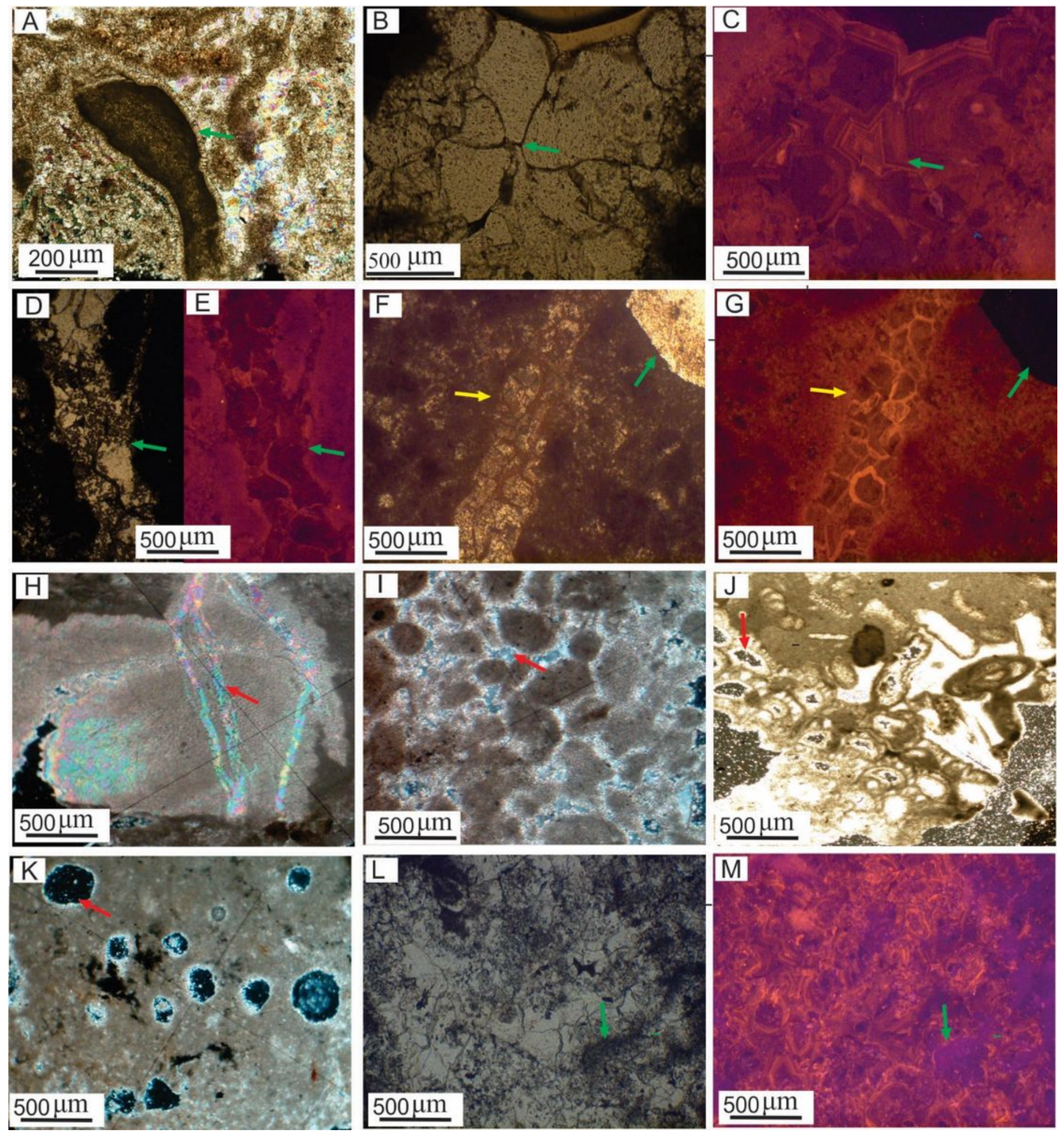

\section{Figure 7}

Diagenetic features of the studied Asmari Formation. A) Isopachous fibrous cement precipitated around an intraclast. B) and C) Respectively transmitted light and corresponding cathodoluminescence image of blocky cement showing bright orange - dull luminescent zones. $D$ and E) Dolomite matrix and vein cement (green arrow) which the matrix reveals uniform pinkish colour in $\mathrm{CL}(\mathrm{E})$ but the vein represents dull luminescence in the (E) with some alteration at the border. F) and G) Calcite matrix and vein with 
attrition in border, the latter showing dull luminescence with yellow zones pointing to late diagenesis. The yellow arrow in both $\mathrm{F}$ and $\mathrm{G}$ showing marine cement. $\mathrm{H}$ ) Vein filled by gypsum cement. I) Interparticle porosity between peloids. J) Framework porosity in bryozoans. K) Moldic porosity in mudstone. L and M) Dolomite which is showing lilac luminescence in $(M)$. The organs colour in (M) is due to telogenetic alteration.
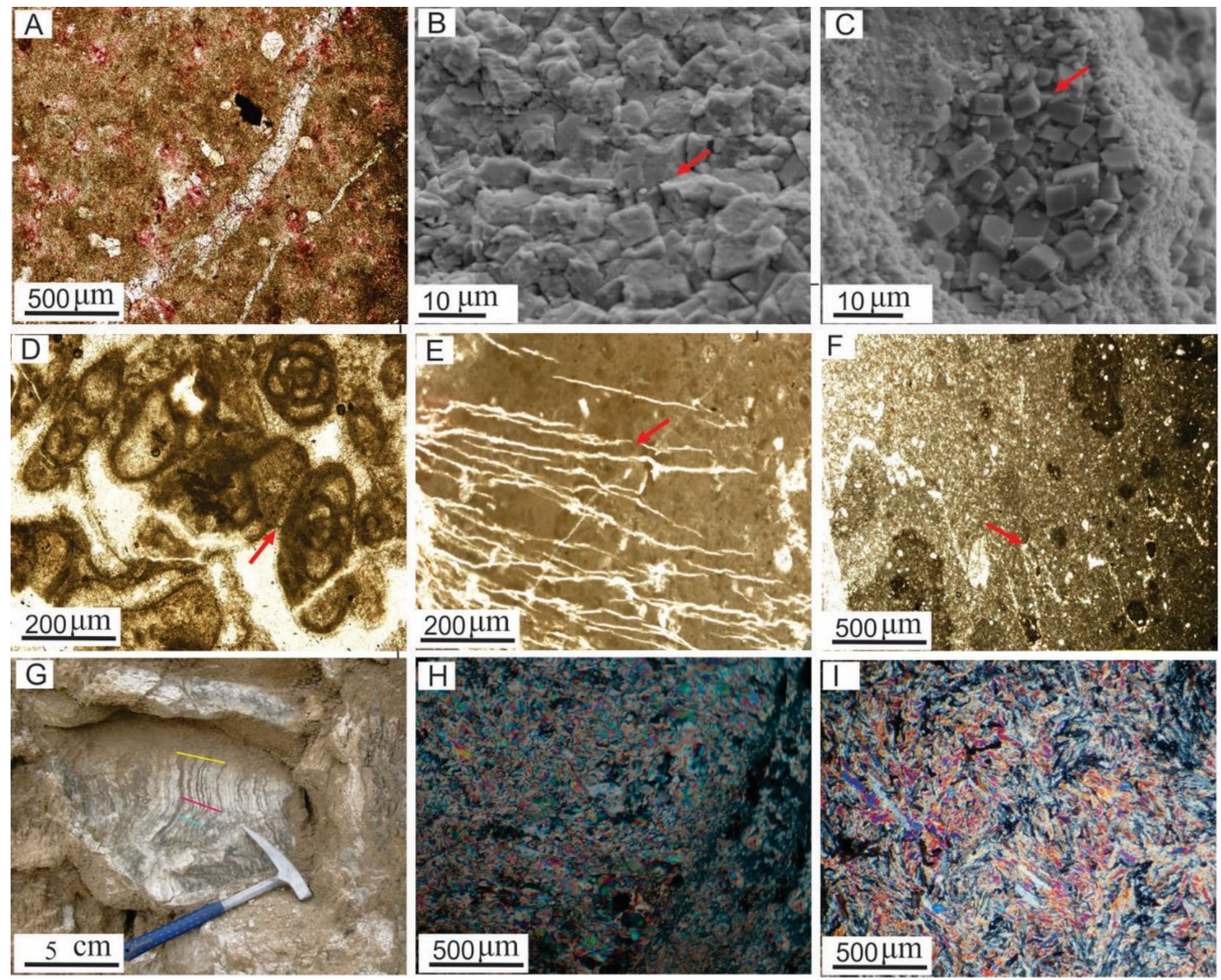

\section{Figure 8}

Diagenetic features of the studied Asmari Formation. A) Dolomitization. B and C) SEM image of dolomitization. D) Mechanical compaction between foraminifera. E) Micro-veins in mudstone. F) Stylolite. G) satin spar gypsum. H) Alabastrine texture. I) Elongated nodular and pseudomorphs of anhydrite. 


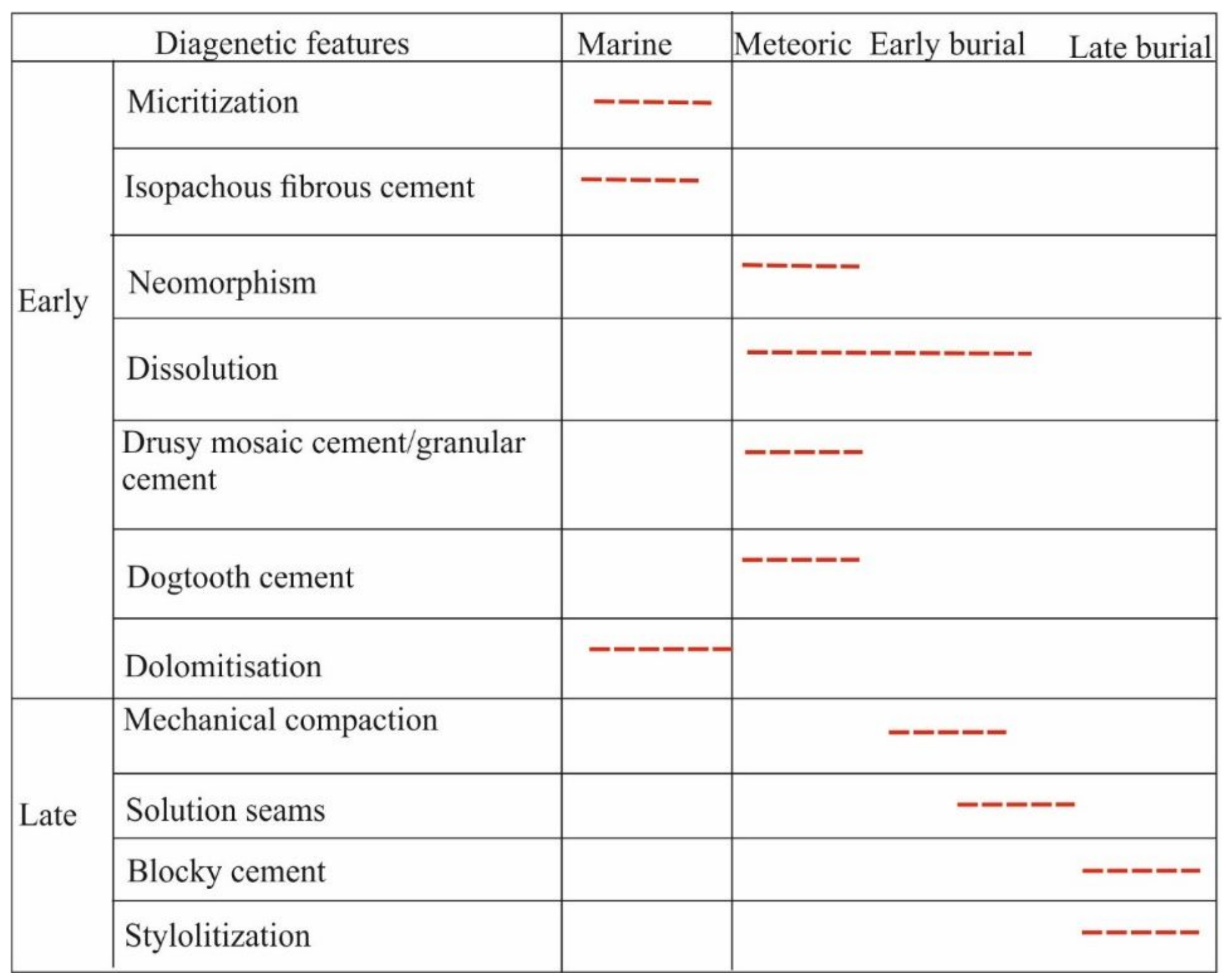

Figure 9

Paragenesis of the Asmari Formation carbonates in the study area. 

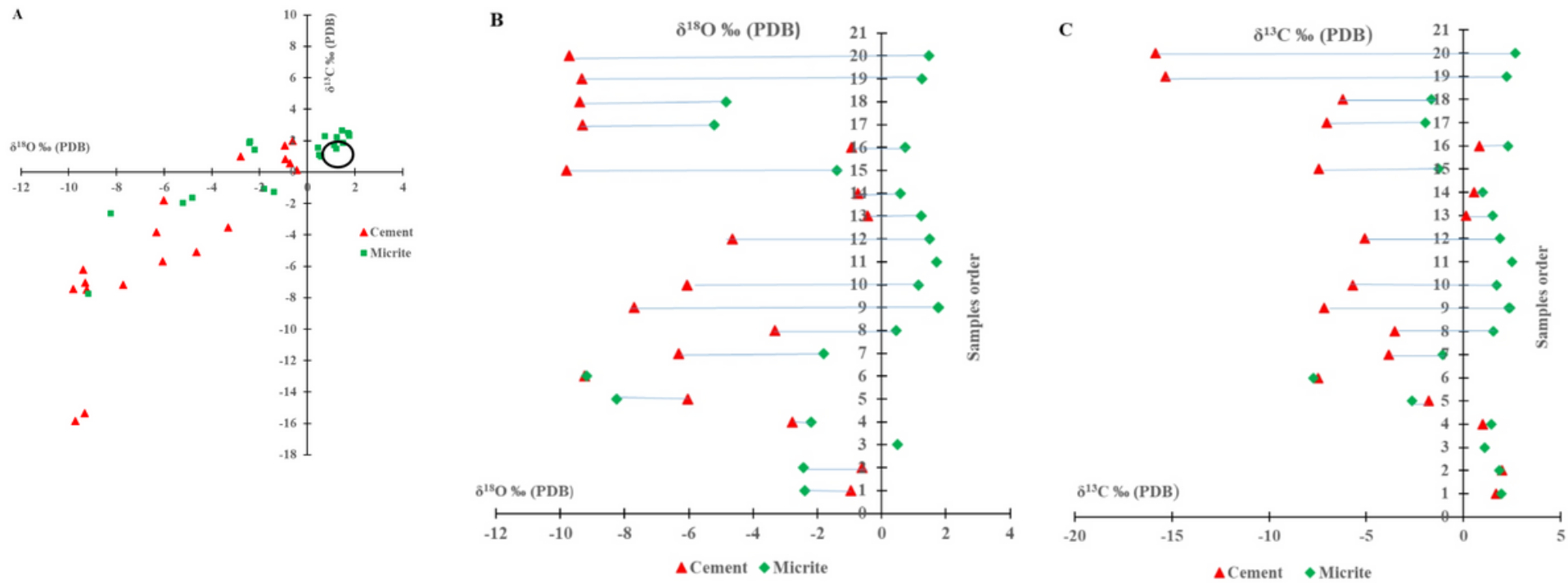

Figure 10

A) Cross plot of stable oxygen versus carbon isotopes of different cement and micrite. The black circle is the reference for carbon and oxygen isotope values reported for Oligo-Miocene marine carbonates (e.g. Vandenberghe et al., 2012). B and C) Vertical evolution of the oxygen and carbon isotope composition within the Asmari Formation. Notice that, in the lower part of Asmari Formation the similar values of $\delta 13 \mathrm{C}$ and similar to enrichment values of $\delta 180$ observed in cement compare to micrite. This testifies to the limited fluid rock interaction, and point toward the existence of buffering system rather than water dominant system. The aforementioned trend changes higher upwards in upper Asmari Formation. 

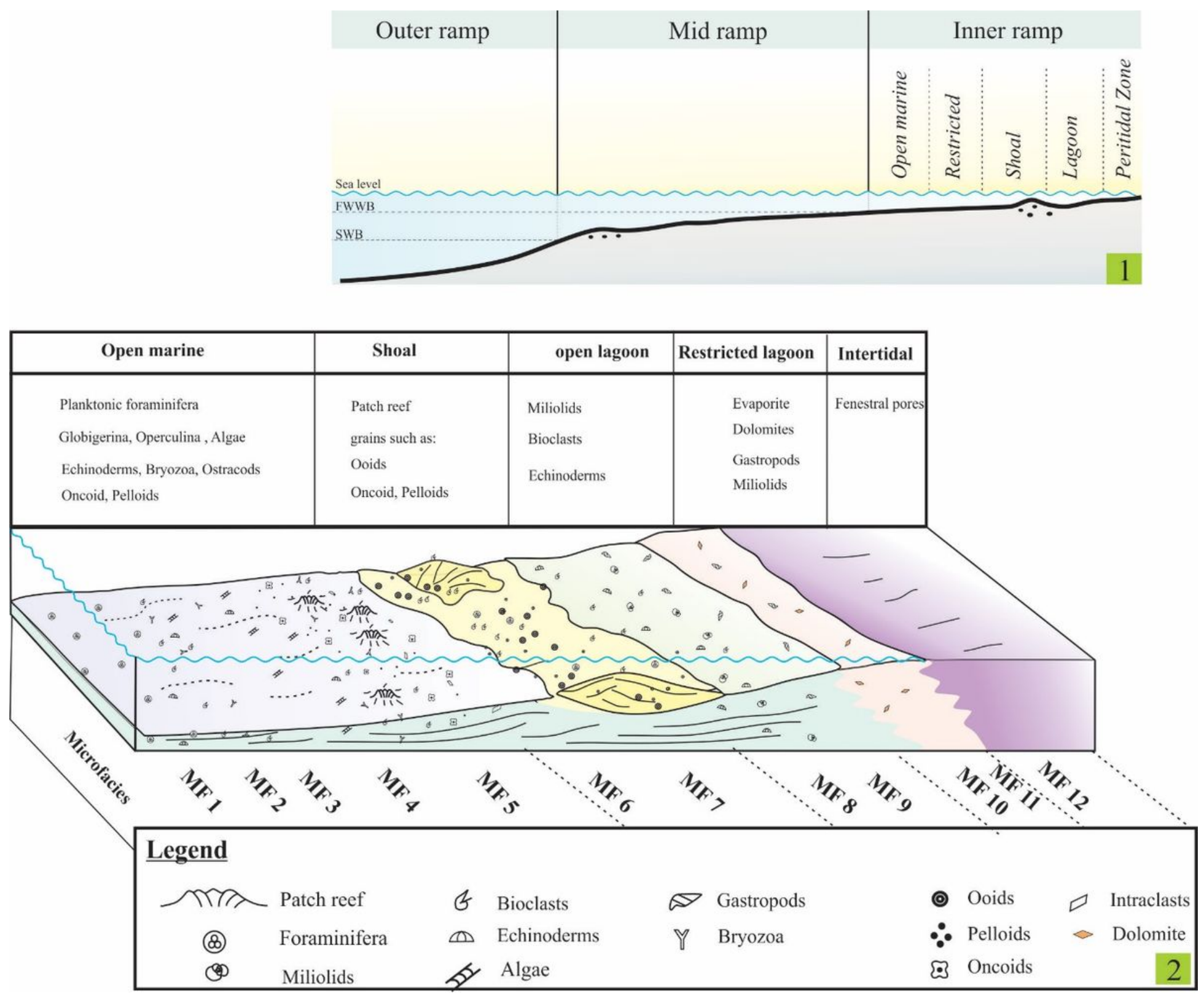

Figure 11

Schematic reconstruction of paleoenvironment with indication of microfacies. 